\title{
HUBUNGAN ANTARA STATUS GIZI DENGAN TEKANAN DARAH MAHASISWA PROGRAM STUDI PENDIDIKAN DOKTER ANGKATAN 2013 FAKULTAS KEDOKTERAN UNIVERSITAS SAM RATULANGI
}

\author{
${ }^{1}$ Yulyius \\ ${ }^{2}$ Alexander S. L. Bolang \\ ${ }^{2}$ Shirley E. S. Kawengian \\ ${ }^{1}$ Kandidat Skripsi Fakultas Kedokteran Universitas Sam Ratulangi Manado \\ ${ }^{2}$ Bagian Ilmu Gizi Fakultas Kedokteran Universitas Sam Ratulangi Manado \\ Email: yulyius_100@yahoo.com
}

\begin{abstract}
Blood pressure is the pressure generated by the blood against the blood vessel. Increase in blood pressure or hypertension is also called a silent killer because it is onlysome of the symptoms. The increase number of patients with hypertension associated with factors are unhealthy diet, physical inactivity, and overweight. The incidence of hypertension in obesity will continue to increase with increasing body mass index and waist hip ratio. This study aimed to determine a relationship between the nutritional status with blood pressure in students of medical education batch 2013 the Faculty of Medicine, University of Sam Ratulangi. The design of this study is using the analytic cross sectional. The study sample is part of the population who meets inclusion and exclusion criteria with total 100 people. Data collected through anthropometric measurementand blood pressure measurement, and data was analyzed using Spearman's rho test. Normal nutritional status ( BMI / U ) results was79\%, overweight and obesity was $16 \%$ and only $5 \%$ of respondents who have malnutrition, waist hip ratio that not risk is equal to $85 \%$, and risk is $15 \%$, whereas $36 \%$ of normotension and prehipetension is $64 \%$.Conclusion: The results of this study concluded that there is a significant relationship between nutritional status ( BMI / U ) on blood pressure with a pvalue is $0.000(p<\alpha=0.05)$, and there is no relationship between nutritional status ( WHR ) on blood pressure systolic with a p-value is 0.0,509 ( $\mathrm{p}>\alpha=0.05)$.
\end{abstract}

Key words: Thenutritional status, blood pressure

\begin{abstract}
Abstrak: Tekanan darah merupakan tekanan yang dihasilkan oleh darah terhadap pembuluh darah.Peningkatan tekanan atau hipertensi merupakan pembunuh diam-diam karena hanya menimbulkan beberapa gejala.Meningkatnya jumlahpenderita hipertensiberhubungan denganperilaku diet yang tidak sehat, kurangnya aktivitas fisik, dan kelebihan berat badan. Angka kejadian hipertensi pada obesitasakan terus meningkat seiring dengan peningkatan indeks massa tubuh dan waist hip ratio. Penelitian ini bertujuan untuk mengetahui hubungan antara status gizi dengan tekanan darah padamahasiswa program studi pendidikan dokter angkatan 2013 Fakultas Kedokteran Universitas Sam Ratulangi. Rancangan penelitian ini bersifat analitik dengan menggunakan pendekatan potong lintang. Sampel penelitian ini merupakan bagian dari populasi yang memenuhi kriteria eksklusi dan inklusi berjumlah 100 orang. Data yang dikumpulkan melalui pengukuran antropometri dan pengukuran tekanan darah, kemudian data dianalisis dengan menggunakan uji Spearman's rho. Status gizi (IMT/U) yang normal sebesar 79\%, gizi lebih dan obesitas sebesar 15\% dan hanya 5\% responden gizi kurang, Waist hip ratio yang tidak berisiko yaitu sebesar 85\%, dan yang berisiko sebesar 15\%, sedangkan normotensi sebesar 36\% dan prehipertensi sebesar 64\%. Kesimpulan:Hasil penelitian ini menyimpulkan bahwa terdapat hubungan yang bermakna antara status gizi (IMT/U) terhadap tekanan darah dengan nilai $p$ yaitu $0,000(\mathrm{p}<\alpha=0,05)$, dan tidak terdapat hubungan antara status gizi (WHR) terhadap tekanan darah sistolik dengan nilai $p$ yaitu 0,0,509 $(\mathrm{p}>\alpha=0,05)$.
\end{abstract}

Kata Kunci: Status Gizi, Tekanan Darah 
Tekanan darah merupakan tekanan yang dihasilkan oleh darah terhadap pembuluh darah. Tekanan darah dapat meningkat ataupun menurun, penurunan tekanan darah disebut hipotensi yang disebabkan oleh bayak faktor diantaranya perdarahan, tidak adekuatnya penggantian cairan (dehidrasi), syok dan lain sebagainya. ${ }^{1}$ Sedangakan peningkatan tekanan darah atau yang disebut juga hipertensi merupakan pembunuh diamdiam karena hanya menimbulkan beberapa gejala, itupun jika ada., ${ }^{2,3}$ Seseorang dapat menderita hipertensi selama bertahuntahun tanpa menyadarinya. ${ }^{2}$

Meningkatnya tekanan darah dapat dipengaruhi oleh banyak faktor diantaranya keturunan, kegemukan, kurangnya aktifitas, dan lain sebaginya. Hipertensi yang tidak terkontrol, maka baik secara langsung maupun tidak langsung dapat menimbulkan kerusakan organ target. ${ }^{4,5}$ Kerusakan organ tersebut akan mempengaruhi prognosis pasien hipertensi. ${ }^{4}$

Hasil beberapa penelitian menggambarkan bahwa hipertensi yang tidak terkontrol dapat meningkatkan peluangterjadinya stroke 7 kali lebih besar, 6 kali lebih besar terkena congestiveheart failure, dan 3 kali lebih besar terkena serangan jantung. ${ }^{5}$ Berdasarkan data WHOpada tahun 2012, prevalensi hipertensisecara

globalmengalamipenurunandari32\% pada tahun 1980 menjadi27\% di tahun 2008, namun di sisi lain, terjadi peningkatandi negara berkembangseperti diAfrikadanAsia Tenggara. ${ }^{6}$

Menurut Riset Kesehatan Dasar (RISKESDAS) tahun 2007 Prevalensi hipertensi pada usia remaja sebesar 8,4\%. ${ }^{7}$ Prevalensi hipertensi menurut Provinsi pada kelompok usia 18 tahun keatas yang dinilai berdasarkan hasil pengukuran tekanan darah yaitu sebesar 31,7\%. Prevalensi tertinggi terdapat pada Provinsi Kalimantan Selatan yaitu 39,6\% dan Papua Barat termasuk prevalensi terendah yaitu 20,1\%, sedangkan pada Provinsi Sulawesi Utara terdapat 31,2\%. ${ }^{7}$

Meningkatnya

jumlahpenderita hipertensiberhubungan

denganpertumbuhan penduduk serta adanyafaktor risikoperilaku diet yang tidak sehat, kurangnya aktivitas fisik, kelebihan berat badandan paparanstrespersisten. ${ }^{8}$ Permasalahan gizi pada orang dewasacenderung didominasi oleh kelebihan berat badan. ${ }^{9} \mathrm{Di}$ seluruh dunia prevalensi obesitasataukelebihan berat, meningkat dua kali lipatantara tahun 1980dan 2008, pada tahun 1980hanya 5\% laki-laki dan $8 \%$ perempuan di duniamengalami obesitas, sedangkan pada tahun 2008, $10 \%$ pria dan $14 \%$ wanita mengalami obesitas. ${ }^{10}$

Menurut Riset Kesehatan Dasar (RISKESDAS) tahun 2010 prevalensi status gizi (kelebihan berat badan atau overweight) di Indonesia pada kelompok remaja umur 16-18 tahun (IMT/U) berdasarkan Provinsi yaitu sebesar 1,4\%, tertinggi terdapat pada Yogyakarta sebesar 4,1 \% sedangkan Provinsi Sulawesi Utara terdapat 2,1\%. Sedangkan pada usia 18 tahun keatas Provinsi Sulawesi Utara termasuk prevalensi tertinggi terhadap obesitas yaitu sekitar 37,1\%, dan yang terendah yaitu sebesar $13,0 \%$ di Provinsi Nusa Tenggara Timur. Prevalensi obesitas pada laki-laki lebih rendah (16,3\%) dibanding perempuan $(26,9 \%){ }^{9}$

Indeks massa tubuh sangat terkait dengan hipertensi. ${ }^{11}$ Angka kejadian hipertensi pada obesitas menurutSwedish Obese Studydidapatkan sebesar 13,5\% dan angka tersebut akan terus meningkat seiring dengan peningkatan indeks massa tubuh (IMT)dan waist-hip- ratio (WHR). ${ }^{12}$ Waist hip- ratio merupakan pengukuran yang mudah, cepat dan tidak invasif yang dapat digunakan yang dapat menggambarkan distribusi lemak tubuh.

Hasil penelitian oleh Aviani RDK dan Sulcan M tahun 2013 menunjukan, prevalensi hipertensi obesitik pada remaja awal sebesar 7,5\%. ${ }^{13}$ Berdasarkan penelitian Hipertensi pada responden obes 
usia dewasa di Indonesia menunjukan, prevalensi hipertensi pada responden obes Sebesar 48,6\%, presentase pada laki-laki obes terdapat $50,1 \%$ dan perempuan $47,9 \%{ }^{12}$ Hasil tersebut lebih tinggi dibandingkan dengan prevalensi hipertensi pada obes yang dilaporkan oleh hasil Swedish Obese Study.

\section{METODE PENELITIAN}

Penelitian ini bersifat analitik dengan menggunakan pendekatan potong lintang dan dilaksanakan di Manado selama bulan Oktober 2013 sampai Februari 2014. Sampel penelitian ini merupakan bagian dari populasi yang memenuhi kriteria eksklusi dan inklusi berjumlah 100 orang. Data yang dikumpulkan melalui pengukuran antropometri dan pengukuran tekanan darah, kemudian data dianalisis dengan menggunakan uji Spearman's rho.

\section{HASIL PENELITIAN}

\section{Karakteristik responden}

Berdasarkan jenis kelamin, jenis kelamin perempuan memiliki distribusi tertinggi yaitu sebesar $70 \%$ sedangkan laki-laki sebesar 30\%. Berdasarkan umur, responden dengan umur 18 tahun memiliki distribusi tertinggi yaitu sebesar $58 \%$. Responden yang tinggal dengan orang tua dan kos memiliki distribusi yang hampir sama, dimana yang tinggal dengan orang tua sebesar 51\% dan kos sebesar 49\%.

Berdasarkan pekerjaan orang tua responden, ayah responden yang bekerja sebagai PNS memiliki distribusi tertinggi yaitu sebesar 53\%, sama halnya ibu responden yang bekerja sebagai PNS sebesar $47 \%$. Responden yang beragama Kristen mendominasi penelitian ini yaitu sebesar 66\%.

\section{Status Gizi}

Distribusi status gizi dapat dilihat pada tabel 1. Berdasarkan indeks massa tubuh terhadap umur (IMT/U) menunjukan bahwa status gizi normal memiliki distribusi tertinggi pada penelitian ini yaitu sebesar $79 \%$ dan obesitas memiliki distribusipaling rendah yaitu sebesar 4\%. Berdasarkan waist hip ratio(WHR), reponden yang tidak berisiko memiliki distribusi tertinggi yaitu sebesar $85 \%$ sedangkan yang berisiko hanya sebesar $15 \%$.

\section{Tekanan Darah}

Tekanan darah sisitolik pada penelitian ini memiliki rata-rata yaitu 116,00 $\pm 8,646 \mathrm{mmHg}$ dengan tekanan darah paling rendah yaitu $100 \mathrm{mmHg}$, tertinggi yaitu $130 \mathrm{mmHg}$. Distribusi tekanan darah dapat dilihat pada tabel 2. Responden yang prehipertensi memiliki distribusi tertinggi yaitu sebesar 64 responden (64\%).

\section{Hubungan Status Gizi Dengan Tekanan \\ Darah}

Distribusi status gizi (IMT/U) terhadap tekanan darah dapat dilihat pada tabel 3. Status gizi normal yang normotensi memiliki distribusi tertinggi yaitu sebesar 39,2\% dan prehipertensi tertinggi terdapat pada obesitas yaitu sebesar 100\%.Distribusi status gizi (WHR) terhadap tekanan darah dapat dilihat pada tabel 4. Responden yang tidak berisiko dan prehipertensi memiliki distribusi tertinggi yaitu sebesar $64,7 \%$ dan responden yang berisiko dan prehipertensi yaitu sebesar $60 \%$.

Hasil uji spearman rho, hubungan status gizi dengan tekanan darah dapat dilihat pada tabel 5. Hasil uji tersebut menunjukan bahwa terdapat hubungan yang bermakna antara status gizi (IMT/U) dengan tekanan darah, dengan nilai $r=0,375$ dan $p=0,00$ $<\alpha=0,05$. Satus gizi (WHR) tidak terdapat hubungan yang bermakna dengan tekanan darah, dengan nilai $r=0,067$ dan nilai $\mathrm{p}=0,509>\alpha=0,05$.

\section{PEMBAHASAN}

Kenaikan tekanan darah atau hipertensi tidak hanya terjadi pada orang dewasa tetapi juga terjadi pada kelompok usia remaja. Tekanan darah pada usia remaja dapat digunakan untuk memprediksi kemungkinan terjadinya hipertensi dikemudian hari. ${ }^{14}$ 
Penelitian yang dilakukan pada 100 studi pendidikan dokter Fakultas responden mahasiswa semester 1 program

Tabel 1. Distribusi responden berdasarkan status gizi

\begin{tabular}{llcc}
\hline & Responden & \multicolumn{2}{c}{ Jumlah } \\
\cline { 3 - 4 } & & $\mathrm{n}$ & $\%$ \\
\hline Indeks Massa & Kurus & 5 & 5 \\
Tubuh/ Umur & Normal & 79 & 79 \\
& Gemuk & 12 & 12 \\
& Obesitas & 4 & 4 \\
Waist Hip Ratio & Tidak Berisiko & 85 & 85 \\
& Berisiko & 15 & 15 \\
\hline
\end{tabular}

Tabel 2. Distribusi responden berdasarkan tekanan darah

\begin{tabular}{lccc}
\hline & Responden & \multicolumn{2}{c}{ Jumlah } \\
\cline { 3 - 4 } & & $\mathrm{n}$ & $\%$ \\
\hline Tekanan Darah & 100 & 9 & 9 \\
Sistolik & 110 & 38 & 38 \\
& 120 & 37 & 37 \\
& 130 & 16 & 16 \\
Tekanan Darah & & & 36 \\
& Normotensi & 36 & 64 \\
\hline
\end{tabular}

Tabel 3. Distribusi responden terhadap Tekanan Darah berdasarkan status gizi (IMT/U)

\begin{tabular}{|c|c|c|c|c|c|c|c|}
\hline \multirow{3}{*}{ Status Gizi } & & \multicolumn{4}{|c|}{ Tekanan Darah (mmHg) } & \multirow{2}{*}{\multicolumn{2}{|c|}{ Total }} \\
\hline & & \multicolumn{2}{|c|}{ Normotensi } & \multicolumn{2}{|c|}{ Prehipertensi } & & \\
\hline & & $\mathrm{n}$ & $\%$ & $\mathrm{n}$ & $\%$ & $\mathrm{n}$ & $\%$ \\
\hline & Kurus & 2 & 40 & 3 & 60 & 5 & 100 \\
\hline Indeks Massa Tubuh/ & Normal & 31 & 39,2 & 48 & 60,8 & 79 & 100 \\
\hline \multirow[t]{2}{*}{ Umur } & Gemuk & 3 & 25 & 9 & 75 & 12 & 100 \\
\hline & Obes & 0 & 0 & 4 & 100 & 4 & 100 \\
\hline Total & & 36 & & 64 & & 100 & \\
\hline
\end{tabular}

Tabel 4. Distribusi responden terhadap Tekanan Darah berdasarkan status gizi (WHR)

\begin{tabular}{|c|c|c|c|c|c|c|c|}
\hline \multirow{3}{*}{ Status Gizi } & & \multicolumn{4}{|c|}{ Tekanan Darah (mmHg) } & \multirow{2}{*}{\multicolumn{2}{|c|}{ Total }} \\
\hline & & \multicolumn{2}{|c|}{ Normotensi } & \multicolumn{2}{|c|}{ Prehipertensi } & & \\
\hline & & $\mathrm{n}$ & $\%$ & $\mathrm{n}$ & $\%$ & $\mathrm{n}$ & $\%$ \\
\hline Waist Hip & Tidak Berisisko & 30 & 35,3 & 55 & 64,7 & 85 & 100 \\
\hline Ratio & Berisiko & 6 & 40 & 9 & 60 & 15 & 100 \\
\hline Total & & 36 & & 64 & & 100 & \\
\hline
\end{tabular}


Tabel 5. Hubungan status gizi dengan tekanan darah

\begin{tabular}{lcc}
\hline Variabel Penelitian & $r$ & $p$ \\
\hline $\begin{array}{l}\text { Status Gizi IMT/U } \\
\text { Tekanan Darah Sistolik }\end{array}$ & 0,375 & 0,000 \\
$\begin{array}{l}\text { Status Gizi WHR } \\
\text { Tekanan Darah Sistolik }\end{array}$ & 0,067 & \\
\hline
\end{tabular}

Indeks Massa Tubuh merupakan metode yang digunakan untuk menentukan status gizi seseorang. ${ }^{15}$ Penilaian status gizi pada remaja yaitu dengan menggunakan perhitungan IMT yang kemudian dicocokan dengan grafik pertumbuhan sesuai dengan usia dan jenis kelamin. ${ }^{9}$

Hasil analisis uji statistik pada penelitian ini menunjukan bahwa, status gizi (IMT/U) mempunyai hubungan yang bermakna dengan tekanan darah sistolik pada Mahasiswa Program Studi Pendidikan Dokter Angkatan 2013 Fakultas Kedokteran Universitas Sam Ratulangidengan nilai $\mathrm{p}=0,000$. Hasil tersebut sesuai dengan hasil yang dilakukan oleh Aina SD dan Guslihan DT (2013 ) di Sekolah Dasar Negeri 064979 Medan, yang menunjukan bahwa terdapat hubungan antara indeks massa tubuh dengan tekanan darah pada anak. ${ }^{16}$ Hasil yang sama yang dilakukan oleh Hendrik (2011) pada mahasiswa Fakultas Kedokteran Universitas Sumatera Utara yang menunjukan bahwa terdapat hubungan yang bermakna antara indeks massa tubuh dengan tekanan darah. ${ }^{17}$

Prehipertensi dan hipertensi berhubungan dengan berbagai komplikasi pada hampir seluruh organ, tetapi sering diabaikan oleh dewasa muda. Perlu dilakukan intervensi sejak dini untuk mencegah penyakit yang lebih lanjut dengan memodifikasi gaya hidup karena tekanan darah berhubungan dengan faktor risiko yang dapat dirubah, seperti IMT dan aktivitas total. $^{6}$

Analisis uji statistik pada penelitian ini menunjukan bahwa, status gizi (WHR) tidak mempunyai hubungan yang bermakna dengan tekanan darah sistolik pada Mahasiswa Program Studi Pendidikan Dokter Angkatan 2013 Fakultas Kedokteran Universitas Sam Ratulangidengan nilai $\mathrm{p}=0,509$. Hasil ini berbeda dengan penelitian yang dilakukan oleh Puspita Sari dkk (2010) di SMAN 4 Semarang yang mengatakan bahwa terdapat hubungan rasio lingkar pinggangpinggul dengan tekanan darah sistolik dan diastolik. ${ }^{14}$ Hasil yang bebeda pula yang dilakukan oleh Pradana NO (2010) di warga desa Mojoroto kota Kediri yang mengatakan bahwa terdapat hubungan antara rasio lingkar pinggang panggul dengan tekanan sistolik. ${ }^{18}$ Perbedaan hasil tersebut disebabkan karena perbedaan distribusi sampel dan faktor yang lain yang ikut berperan.Keseimbangan akumulasi lemak ditentukan oleh sintesis lemak (lipogenesis) dan pemecahan lemak (lipolisis- oksidasi asam lemak). Peningkatan risiko penyakit berhubungan dengan kelebihan lemak viseral dan bukan lemak subkutan pada tubuh. ${ }^{15}$

Obesitas merupakan suatu keadaan dimana terdapat akumulasi lemak yang berlebihan pada jaringan adiposa yang dapat menyebabkan gangguan pada kesehatan.Hal ini terkait dengan sindroma metabolik diantaranya yaitu resistensi insulin, intoleransi glukosa maupun hipertensi. ${ }^{15}$ Peningkatan tekanan darah merupakan suatu keadaan dimana tekanan darah meningkat melebihi tekanan darah normal. Penyebab tekanan darah meningkat diantaranya peningkatan kecepatan denyutan jantung, peningkatan resistensi pembuluh darah tepi dan peningkatan volume darah. Faktor gizi 
berhubungan dengan terjadinya hipertensi melalui beberapa mekanisme. Faktor usia juga berperan, karena pada usia lanjut pembuluh darah cenderung menjadi kaku dan elastisitasnya berkurang. ${ }^{4}$

\section{KESIMPULAN}

Status gizi (IMT/U) yang normal sebesar $79 \%$, gizi lebih dan obesitas sebesar $16 \%$ dan hanya $5 \%$ responden yang memiliki gizi kurang. Waist hip ratio yang tidak berisiko yaitu sebesar 85\%, sedangkan yang berisiko sebesar $15 \%$. Tekanan darah normotensi sebesar 36\% dan prehipetensi sebesar 64\%. Terdapat hubungan yang bermakna antara status gizi (IMT/U) dengan tekanan darah sistolik sedangkan status gizi (WHR) tidak terdapat hubungan dengan tekanan darah sistolik pada mahasiswa program studi pendidikan dokter angkatan 2013 Fakultas Kedokteran Universitas Sam Ratulangi.

\section{SARAN}

Berdasarkan hasil yang didapatkan pada penelitian ini, maka perlu diajukan saran sebagai berikut: Mengontrol status gizi secara berkala, sehingga dapat diketahui masalah gizi secara dini.Mengontrol tekanan darah secara berkala, sehingga dapat mengetahui peningkatan tekanan darah secara dini. Perlu dilakukan penelitian lebih lanjut tentang status gizi dengan tekanan darah yang berhubungan dengan faktor-faktor lain

\section{DAFTAR PUSTAKA}

1. Baradero M, Dayrit MW, Siswadi Y. Keperawatan Pascaoperatif. Dalam: Ariani F, Ester M, editor. Prinsip dan Praktik Keperawatan Perioperatif. Jakarta: EGC; 2009. h. 100.
2. Nugroho AW, Santoso N. Ilmu Gizi Menjadi Sangat Mudah. Edisi ke-2. Jakarta: EGC; 2011. h. 246-247.

3. Wangdi T. Burden, determinants and control of hypertension: a Bhutanese perspective. Regional healt forum.2013;17:20-5.

4. Yogiantoro M. Hipertensi Esensial. Dalam: Sudoyo AW, Setiyohadi B, Alwi I, K Simanibrata M, Setiana S. Syam AF, dkk, editor. Buku Ajar Ilmu Penyakit Dalam. Edisi ke-5. Jakarta: Interna Publishing; 2010. h. 1079-85.

5. Rahajeng E, Tuminah S. Prevalensi Hipertensi dan Determinannya di Indonesia. Maj Kedokt Indon. 2009;59:580-7.

6. Widjaja FF, Santoso LA, Barus NRV, Pradana GA, Estetika C. Prehypertension and hypertension among young Indonesian adults at a primary health care in a rural area.Med J Indones. 2013;22:37-45.

7. Riset

Kesehatan

Dasar(RISKESDAS). 2007. h.111-2. [Diakses 23 Oktober 2013]. Tersedia di

http://www.k4health.org/sites/default/f iles/laporanNasional\%20Riskesdas\%2 02007.pdf.

8. MendisS. Hypertension: a silent contributor to the global cardiovascular epidemic. Regional healt forum. 2013;17:1-5.

9. Riset

Kesehatan

Dasar(RISKESDAS). 2010. h.39-66. [Diakses 16 0ktober 2013]. Tersedia di http://www.litbang.depkes.go.id/sites/ download/buku_laporan/lapnas_riskes das2010/Laporan_riskesdas_2010.pdf.

10. Hartono B. Empowering the community to fight against 
hypertension:the

Indonesian

experience. Regional healt forum. 2013;17:32-7.

11. Verma A, Patel P, Pate JR, Chaudhary H. Relation of BMI \& hypertension in natives of Gujarat. GCSMC J Med Sci. 2013;2:17-9.

12. Sihombing M. Hubungan Perilaku Merokok, Konsumsi

Makanan/Minuman, dan Aktivitas Fisik dengan Penyakit Hipertensi pada Responden Obes Usia Dewasa di Indonesia. Maj Kedokt Indon. 2010;60:406-12.

13. Avihani RDA, Sulchan M. Densitas Energi Makanan dan Hereditas Sebagai Faktor Risko Hipertensi Obesitik pada Remaja Awal. Journal of Nutrition College. 2013;2:69-72.

14. Sari P, Wirawani, Yekti. Hubungan Rasio Lingkar Pinggang-Pinggul Dan Asupan Natrium Dari Western Fast Food Dengan Tekanan Darah Pada Remaja (Thesis). Semarang: Program Studi Ilmu Gizi; 2010.

15. Sugondo S. Obesitas. Dalam: Sudoyo AW, Setiyohadi B, Alwi I, K Simanibrata M, Setiana S. Syam AF, dkk, editor. Buku Ajar Ilmu Penyakit Dalam. Edisi ke-5. Jakarta: Interna Publishing; 2010. h. 1973-83

16. Sarah AD, Tjipta GD. Hubungan Indeks Massa Tubuh dengan Tekanan Darah Anak di Sekolah Dasar Negeri 064979 Medan. E-jurnal FK USU. 2013;1.

17. Hendrik. Hubungan indeks massa tubuh dengan tekanan darah pada mahasiswa fakultas kedokteran universitas sumatera utara (Skripsi). Sumatera Utara: Universitas Sumatera Utara; 2011.
18. Oviyantin PN. Hubungan antara lingkar pinggang dan rasio lingkar pinggang panggul dengan tekanan darah pada subjek usia dewasa (Skripsi). Surakarta: Universitas Sebelas Maret; 2010. 